\title{
Benign Epicardial Neoplasm
}

National Cancer Institute

\section{Source}

National Cancer Institute. Benign Epicardial Neoplasm. NCI Thesaurus. Code C8535.

A non-metastasizing neoplasm that affects the inner layer of the pericardium. 